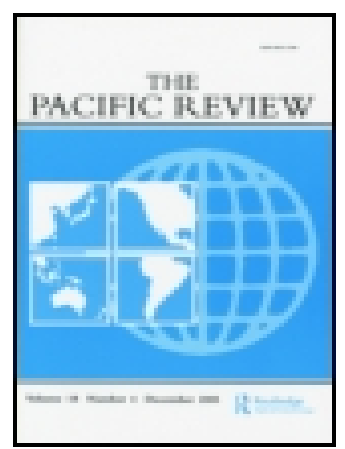

The Pacific Review

ISSN: (Print) (Online) Journal homepage: https://www.tandfonline.com/loi/rpre20

\title{
The productive power of rising China and national identities in South Korea and Thailand
}

\section{Alexander Bukh}

To cite this article: Alexander Bukh (2021): The productive power of rising China and national identities in South Korea and Thailand, The Pacific Review, DOI: 10.1080/09512748.2020.1868557

To link to this article: https://doi.org/10.1080/09512748.2020.1868557

册 Published online: 05 Jan 2021.

Submit your article to this journal $\pi$

Џ Article views: 278

Q View related articles ¿

View Crossmark data 


\title{
The productive power of rising China and national identities in South Korea and Thailand
}

\author{
Alexander Bukh \\ Political Science and International Relations Programme, Victoria University of \\ Wellington, Wellington, New Zealand
}

\begin{abstract}
Drawing on the insights of the constructivist school approach, this article joins the debate on the effects of rising China in Asia. The existing scholarship devoted to no-material aspects of China's rise focused either on China's 'soft power' initiatives or their reception by certain audiences. In this article, rising China and its governance model, are construed as a form of productive power, one that is expected to bring about not only shifts in material relations and perceptions but also transformations in the national identities of countries in the region. This article focuses on South Korea and Thailand, two countries with fundamentally different political systems but a similar pattern of recent interactions with China. It analyzes the policymaking elites' discourse and public attitudes and explores the productive effects of China's rise on national identities in the two countries. This article argues that the impact of China's rise on elites' discourse has been largely negligible with narratives on kinship and historical ties being used by the elites mostly for instrumental reasons. At the same time, this article suggests that the recent shifts in public attitudes towards greater acceptance of authoritarian values observed in South Korea and Thailand, may be indicative of the productive effect of rising China on national identities in both countries.
\end{abstract}

KEYWORDS Rising China; constructivism; productive power; national identity; Thailand; South Korea

\section{Introduction}

Rising China is increasingly seen by many in the West and beyond, as not only an economic or a security challenge but as an ideological one, namely, as a threat that emanates from the Chinese economic and political model and undermines the basic tenets of liberal democracy (e.g. Anderlini \& Smyth, 2017; Rolland, 2020). In other words, there is a growing perception that China's rise may lead to increasing support for authoritarianism by 
impacting the existing normative structure in countries it is interacting with. This paper seeks to explore such effects of China's rise in relation to national identities in South Korea and Thailand-two countries with distinct political systems but a similar pattern of relations with China.

The academic debate on the effects of China's rise in the Asia-Pacific region has evolved along two axes. On one hand, the rational choice literature has focused on exploring the balancing, hedging, or accommodation policies of various states in the region (e.g. Cheng-Chwee, 2008; He, 2008; Lee, 2017; McDougall, 2012; Narramore, 2008; Ross, 2006; Shekhar, 2012). The other body of literature, more relevant to this paper, has mostly operated within the 'soft power' paradigm, introduced by Joseph Nye in the late 1980s as part of his refutation of America's decline (Nye, 1990) but since then interpreted and applied in myriad ways. Starting with the oftcited book by Joshua Kurlantzick (2007) on China's 'charm offensive', this body of literature has analyzed the various 'soft' tools and resources Beijing has utilized to improve its image in the region, to influence them into adopting policies that favor Beijing, the policy effects such efforts have induced or failed to do so, and the perceptions of China across the region (e.g. Cho \& Jeong, 2008; Holyk, 2011; Huang, 2013; Huang \& Ding, 2006; Lahtinen, 2015; Lai \& Lu, 2012; Shambaugh, 2015; Sonoda \& Goodman, 2018).

By utilizing the notion of 'productive power' this paper takes a different approach to exploring the effects of China's rise. Following Barnett and Duvall $(2005$, p. 56) I define productive power as a diffuse transformative process that produces new meanings and constitutes social subjects through changes in systems of knowledge and discursive practices. This definition of productive power is not dissimilar to Bourdieusian notion of symbolic power, which is defined as the structuring power that constructs reality, creates a certain social consensus regarding the social world and naturalizes and legitimizes social hierarchies (Bourdieu, 1979). As a particular system of knowledge, symbolic power 'brings things into being' by creating a particular vision of the world (Webb, Schirato, \& Danaher, 2002, p. 95).

Productive, or symbolic, power therefore, is directly related to national identity, which, following the constructivist school of International Relations (IR) is understood here as a socially constructed and multilayered understanding of the collective national 'self'. Namely, following the above definition, productive power generates new meanings, systems of knowledge and social consensus, or, in other words, it shapes the social cognitive structure. The latter comprises national identities (Hopf, 2002, p.20-23) and therefore any transformations in social cognitive structures should lead to transformations in national identities. Now, IR scholarship is divided on the 
ontological question of what defines national identity, norms or differentiation from significant 'others' (Rumelili, 2004). Here I suggest a synthesis of the two approaches.

No doubt, social and political norms, or, collective expectations of proper behavior, play an important role in identity construction (Finnemore \& Sikkink, 1998; Jepperson, Wendt, \& Katzenstein, 1996). At the same time, identities are relational, namely they are constituted through difference in which, the collective 'self' is defined through differentiation from its 'others' (Neumann, 1996.) As such, it is only in this process of delineation of the borders of the collective 'self' that political norms become a meaningful identity category by defining the borders of the democratic 'self' for example, in juxtaposition to non-democratic 'others' (Rumelili, 2004, p. 31). Importantly, this differentiation, or the drawing of borders between the 'self' and its 'others', does not occur in a vacuum. First, it is a social process, in which interactions with the 'other' may confirm and reproduce the existing borders, or, especially in the case of inclusive identities based on norms rather than on inherent characteristics, may result in their transformations (Bukh, 2010, pp. 98-104). Second, power plays an important role in shaping this process of differentiation. Namely, identity is a process in which symbolic boundaries between the 'self' and its 'others' are produced within the play of specific modalities of power. These boundaries therefore are not contingent but tend to reflect the broader relations of power between the 'self' and its 'others' (Hall, 2000).

Based on the above definition of productive power and national identity, we can expect that changes in China's relative power relations as well as the nature of its interactions with countries in the region, would be accompanied by certain transformations in the symbolic boundaries that define the national 'self' in relation to China, and in political norms associated with these boundaries.

Language occupies a central place both in both the Barnett and Duvall's conception of productive power and in the Bourdieusian notion of symbolic power. China, however, does not have a coherent counter-discourse it presents to the world, or as Mandelbaum has put it, does not have a 'crusading ideology' (2019, p. 124). Indeed, Chinese elites do deploy certain narratives aimed at influencing various external audiences' perceptions of either certain policies currently pursued by China or important historical events (e.g. Gustafsson, 2014; Hagström, 2015). However, the normative narratives emanated by China's leadership today are rather ambiguous and occasionally self-contradictory. The Chinese discourse on the new world order consists mostly of, as Rolland (2020, p. 3) has put it, 'cryptic or bland formulations'. The Confucius Institute project, considered to be China's main tool for overseas propaganda, lacks in normative or ideational 
resources (Lo \& Pan, 2016, p. 517). Its efforts are concentrated on creating a favorable view of China by suppressing discussions of very specific topics such as Tibet, Taiwan, and the 1989 Tiananmen crackdown and do not present a universal China-centered political discourse (Hughes, 2014; The Conservative Party Human Rights Commission, 2019).

Arguably however, productive power is not necessarily a result of a new discourse introduced by its wielder but can also emanate solely from actions and practice. To illustrate this point, let us briefly look at the rise of another Asian power, Japan, that occurred more than a century ago. The most profound productive effect of Japan's rise was brought about by its defeat of Russia during the Russo-Japanese War. By dealing a severe blow to the hierarchical West/East dichotomy firmly ingrained not only in the minds of the colonizers but also the colonized (Marks, 2005), Japan's victory spurred the rise of national consciousness and the emergence of anticolonial national movements across Asia and beyond. Importantly, this productive effect of the victory was not only unintended but went against the extensive discursive efforts of the Japanese elites aimed at precluding the emergence of the perception of the war in terms of the racial 'East/West' dichotomy (Oguma, 2002, pp. 143-155). In other words, Japan's defeat of Russia had a productive effect on national identities of colonized peoples even though Japan, the unwilling wielder of this productive power, promoted a discourse aimed at suppressing such effects.

Compared to Japan's ascendance over a century ago, China's rise is occurring within a fundamentally different international political environment, but, nevertheless, its practice also constitutes an important intervention into the dominant political discourse. China's model is that of an economically successful, highly centralized party-state which, as in the case of the Great Firewall or the recent massive detentions of Uyghurs, decides and arbitrary implements policies that circumvent individual freedoms for the benefits of, what its leadership sees, as greater social stability. This model constitutes an important intervention into today's dominant liberaldemocratic discourse as it shows that economic success and political freedoms are not necessarily indivisible, and the former can be achieved without the latter (Bates and Huang, 2006, p. 19).

This paper seeks to explore the productive effects of China's rise on collective identities in South Korea and Thailand- two countries with strikingly different political systems but with a rather similar pattern of generally good relations with rising China. The importance of the two countries' for understanding the impact of rising China, recent developments in their respective relations with China, as well as the similarities and the differences in the two dyads will be reviewed in the following section. 
The last question to be considered in this section is a methodological one. What texts or discourses should be chosen as representative of national identity constructs and therefore can offer evidence of productive power effects? In other words, where exactly is the national 'stock of knowledge' (Berger \& Luckmann, [1966]1980, p. 39) located? Constructivist IR scholarship does not offer a univocal answer to this question. Texts examined by it as representative of national identity range from newspapers, popular novels, and specialized journals (e.g. Hopf, 2002) to textbooks (e.g. Bukh, 2007) and writings and speeches made by politicians and political commentators (e.g. Suzuki, 2015). Here I focus on two distinct locales- policy making elites' discourse and public opinion polls. The choice is made for both methodological and instrumental reasons. Since my main interest here are the possible shifts in political norms that form national identity, political elites' and the general public's understanding of such norms seem to be the most pertinent locales for exploring such shifts. These locales are not exhaustive. However, a truly comprehensive analysis of the possible shifts in systems of knowledge and discursive practices that will cover multiple social locales is a task that is well beyond the scope of a journal article.

In the third part I use the methods of discourse analysis to examine the elites' discourse on the two countries' relations with China. One of the most often voiced critiques directed at constructivist analysis is its excessive focus on language and disregard of its possible deployment by actors for purely strategic or instrumental reason in pursuit of rational goals (Fearon and Wendt, 2013). This section will explore such possibility by juxtaposing the discourse deployed by the elites with other pieces of evidence. In the fourth section I use quantitative methodology and apply it to Asian Barometer and World Values Survey data to measure shifts in public attitudes towards norms directly related to the Chinese model. The reasons for choosing these sets of data as well as the methodology used are explained in detail at the beginning of the section.

The results of this study suggest that while the transformations in the elites' discourse were mostly instrumental, the public-level normative structure in both countries has shifted towards greater acceptance of authoritarian values. The latter trend I argue, could be interpreted as indicative of certain productive effects of the Chinese model.

\section{Why South Korea and Thailand?}

There are certain important similarities and differences in the two countries' relations with China that make them particularly interesting for exploring and comparing the productive power of China's rise in Asia. Both had a 
long history of interactions with China under the tribute system. Contrastingly, during the Cold War, both South Korea and Thailand were members of the US-led camp and generally viewed communist China as a major threat to the regional stability. While the post-Cold War transformations in Southeast Asia have been more profound than those on the Korean Peninsula, both countries continued to maintain close security ties with the US (Blaxland \& Raymond, 2017; Bong, 2016). At the same time, over the last three decades, both have also developed a rather close relationship with China.

During the first decades of the Cold War, Thailand's relations with People's Republic of China went through various ups and downs with tensions being at their highest in late 1960s. The increasing intra-communist rivalry between China and Vietnam however, led to a gradual improvement in Sino-Thai relations in mid 1970s, culminating in a formation of an informal alliance between the two countries in opposition to Vietnam in late 1970s (Chambers, 2005). During the 1980s and 1990s the close bilateral ties expanded from covering narrow security interests to economic ones. Trade between the two countries has continued to grow during this period but from early 2000s onwards the growth became exponential. Between 2002 and 2010, bilateral trade between China and Thailand grew eight-fold and in 2014 China overtook Japan to become Thailand's top trading partner (Aiyara, 2020, pp. 77-78). Largely conflict-free and driven by mutual interests, political relations between the two countries have also improved significantly over years and grew closer and warmer. Visits by top-level politicians are frequent and the cooperation between the two countries is extensive (Chantasasawat, 2006). These relations became even closer after the 2014 coup which was denounced by the US and many other Western countries.

The expansion of state-level and trade ties has been accompanied by a sharp increase in the movement of people between the two countries. In 2018, with over 28,000 students studying in China, Thailand occupied the second place as the country of origin for foreign students (Ministry of Education PRC, 2019). The demand for Chinese language education in Thailand has also been rising with over half a million Thais learning Chinese already in early 2010s (Tungkeunkunt \& Phuphakdi, 2018, p. 159). Today, the number of Confucius Institutes in Thailand is one of the largest in the world (Dig Mandarin, 2020). The numbers of Chinese students in Thailand have also continued to grow and while Thailand is only 12th in the list of most favored overseas study destinations for Chinese, the enrolments have doubled in 2017 compared to 2012, with the overall number of Chinese students in the country being estimated at 30,000 (VOA News, 2019). The numbers of Chinese tourists in Thailand have also continued to show an impressive growth and in 2019 
their numbers reached 11 million accounting for more than $25 \%$ of all international tourist arrivals (Bangkok Post, 2020).

Similar developments can be also observed in South Korea's relations with China. China's diplomatic relations with South Korea have not been as smooth as with Thailand, with issues related to North Korea, maritime disputes and diverging interpretations of the ancient kingdom of Goguryeo, often causing tensions (Ye, 2016). These disputes however have been managed relatively well by both governments, preventing them from causing significant long-term damage. In 2008, bilateral relations were upgraded to 'strategic cooperative partnership' and overall, developed smoothly until the 2016 THAAD missiles related frictions. Economic exchanges between the two countries go back to the 1970s but bilateral trade has experienced a rapid growth since the establishment of diplomatic relations in 1992. In 2004, China became Korea's largest overall trading partner, the top destination for Korean exports and second only to Japan in terms of imports (Kim, Kim, \& Lee, 2006, p. 385). Since early 2010s, China has also been South Korea's largest source of foreign students, tourists, and the top travel destination for South Koreans (Ye, 2016). Already in mid 2000s, South Korea became the top country of origin for foreign students in China and continues to maintain this position till the present day (Ministry of Education PRC, 2019; Snyder, 2009, p. 3). Today, South Korea is the home to the largest number of Confucius Institutes in the world. Tourism in both directions has also thrived. In 2018, Chinese tourists accounted for about one third of all international visitors to South Korea and South Korean tourists topped the list of international tourists to China with 4 million visitors (Korea Tourism Organization, 2020; Statista, 2020).

The above shows that from mid 2000s onward, China's presence in both countries as well as bilateral relations have significantly deepened. This increasing 'thickness' of bilateral relations has not been limited to trade but also manifested itself in the movement of people in both directions, making their relationship with China rather unique. The absence of contentious issues that go to the core of national identity narratives between South Korea ${ }^{1}$ and Thailand on one side, and China on the other also makes them potentially more susceptible to China's productive power than other nations in Asia.

Certain similarities can be also observed in the political and ideological developments in both countries' during the Cold War. Both went through a prolonged period of a military rule and had faced pro-democracy movements in the 1970s and 1980s. In both countries the elites' enacted national identity discourses developed and evolved along similar trajectories during the Cold War era. In South Korea, throughout the Cold War years, the dominant national ideology advocated by successive dictators and ruling elites emphasized ethnic 
nationalism and anti-communism (Shin, 2006, p. 103). In 1970s, as part of an effort to strengthen his hold on power, President Park Chung-hee introduced the concept of 'indigenous democracy' which meant the primacy of national security and economic development over individual freedoms as another important element of Korean national identity (Kim, 2011).

In Thailand, the Cold War played a similarly important role in shaping the national identity construct advocated by the ruling elites. The discourse of the nation, religion and monarchy as key pillars of Thai national identity goes back to the 1920s. This trinity however, gained new meaning and achieved its centrality in the officially endorsed construction of Thai national ideology from late 1950s onwards, after Sarit Thanarat's coup and the subsequent reinvigoration of the monarchy under his rule. Under Sarit's rule anti-communism became one of the main pillars of the state ideology (Chachavalpongpun, 2011, p. 1024). Just like in South Korea, the notion of democracy was re-interpreted and adjusted to fit the authoritarian style of governance. 'Thai style democracy' as advocated by Sarit meant suppression of the institutional elements of democracy and primacy of economic development over individual rights (Connors, 2007, pp. 33-52).

In late 1980s, both countries embarked upon a process of political democratization but here the similarities end as the trajectories of their subsequent political developments took them into strikingly different directions. The June 1987 anti-regime mass protests in South Korea have ended the almost three decades of military rule in the country and put the country on the path to democracy. First free and direct presidential elections were conducted in Korea in the same year, and a decade later, Kim Dae-jung, a decades-long leader of the Korean democratization movement, was elected to became South Korea's president. Democracy continued to evolve in South Korea. In 2017, dubbed by some observers as a 'democratic miracle' (Chang, 2017), persistent and peaceful mass protests resulted in the ousting of the increasingly authoritarian President Park Geun-hye. While certain problems remain, today's South Korea is seen as one of the most vibrant democracies in the world, rated as 'free' with a total 'freedom score' of 83 by the Freedom (2020).

In contrast, Thailand went through three military coups in the last three decades, with the most recent one launched in May 2014, after months of domestic instability and crisis. Today, Thai government is headed by the former leader of the junta that ruled Thailand for four years and the military continues to play a decisive role in Thai politics and in shaping the public discourse. As such, Thailand took a direction opposite to the South Korean one, to a certain extent returning to its Cold War era style of governance. Not surprisingly, in 2020 Freedom House (2020) rated Thailand as only 'partially free' with a total 'freedom score' of 32. 
To summarize, during the last two decades, both Thailand and South Korea's relations with China have expanded significantly. At the same time, the political systems in the two countries have developed in oppositional directions, with South Korea embracing Western-style democracy and Thailand growing increasingly authoritarian.

\section{Elite discourse and rising China}

\section{Thailand}

When exploring the impact of China's rise on Thai elites' identity discourse, one cannot ignore the unique place the Chinese ethnic minority has occupied in Thai society and in its national identity construction. While occasionally used as the 'other' against which Thainess was defined, the ethnic Chinese traders have generally maintained a close alliance with royalist political elites throughout Thailand's modern history and were included in the realm of the collective 'self' as defined by the elites. The ethnic component however remained an important part of the Thai Chinese identity (Wongsurawat, 2019). When Deng Xiaoping initiated structural reforms in late 1970s, Thai business leaders of Chinese descent saw the opportunities created by the opening of China. They skillfully used their family connections to forge close relationships with Chinese leadership, and to advance their business interests. For example, Dhanin Chearavanont, one of Thailand's richest people and one of its first investors in China, has extensive ties with the CCP leadership that go back to the 1980s (Chearavanont, 2016). The rise of China in the 21 st century however, had an impact that went beyond the economic interests of the business elites but also on the ways the broader group of Thais of Chinese descent who by now, accounted for the majority of urban elites, viewed and expressed the ethnic element of their identity domestically. Namely, China's emergence as an economic powerhouse legitimized pride in Chinese origins and many Thai businessmen and politicians of Chinese origin started to openly emphasize their Chineseness (Phongpaichit \& Baker, 2009, pp. 11-12). This new pride in the Thai Chinese identity was accompanied by the re-emergence of the elite discourse on Thai-China relationship as kinship, as a relationship between brothers.

The origins of the kinship discourse date back to the first half of the 20th century but it was re-discovered by the Thai elites in late 1980s, after the normalization of bilateral relations, and since then has gained prominence in depictions of bilateral relations made by politicians, government officials and business elites. This discourse relies on the ethnic proximity between the two nations emphasizing the presence of a large Chinese ethnic minority in Thailand and the close historical ties between the two 
nations (Busbarat, 2016a; Tungkeunkunt \& Phuphakdi, 2018). References to Thailand-China relations as familial one can often be often seen in the domestic media and in speeches at events that involve representatives from both countries. In a speech to celebrate the legacy of Kukrit Pramoj, Thailand's former Prime Minister who established diplomatic relations with China in 1975, another former Prime Minister, Anand Panyarachun (2011), noted the omnipresence of the phrase 'Thailand and China are brothers' in the Thai society and presented it as evidence of Kukrit's legacy and success in drawing the two nations closer together. Wissanu Kreangam, Deputy Prime-Minister in Thaksin's government (2002-2006), referred to Thailand's relationship with China as a special one, 'rarely seen among other countries', based on close, family-like ties on all levels of the society (Boontarahan, 2015). In 2005, Thaksin himself referred to Thai and Chinese as belonging to one family during a visit to his ancestor's tomb in mainland China (Zawacki, 2017, p. 133). The prominence of the 'kinship' narrative in Thai elite discourse on relations with China has remained intact despite the various political upheavals in the country. In October 2015, a year and a half after the coup that brought to power the military junta in Thailand, the two countries celebrated the 40th anniversary of establishment of diplomatic relations. During the celebration to commemorate the event, the phrase 'Thailand and China are not strangers, but siblings' as well as depictions of close ethnic, historical and cultural ties, featured prominently in the speeches of many Thai officials including the Foreign Minister Don Pramudwinai (MOFA Thailand, 2015). The reference to the brotherly relations between the two nations often features in speeches by the Thai officials directed at the Chinese audience as well. For example, one of the leaders of the junta, General Prawit Wongsuwan, used this phrase in a speech aimed at reassuring the Chinese tourists about the safety of Thailand after the 2018 Phuket boat capsizing incident (Phanthong, 2020).

Since the early 1980s, the Thai royal family has also played an important role in the promotion of Thailand's relations with China and in the creation of the kinship image. Visits by royal family, televised and widely covered in Thai press have been one of the most important sources for this image for the Thai people (Thirawit, 2005, p. 12). Especially active in promoting ThaiChina relations has been Princess Sirindhorn, a prominent philanthropist and educator, who, in 2019, was awarded the Friendship Medal by the Chinese government for her long dedication to promoting bilateral friendship. Well-known as a Sinophile, Princess Sirindhorn even wrote a poem that described the friendship between two nations as friendship between brothers that 'will last thousand years and beyond' (Zawacki, 2017, p. 134). In her speeches, the Princess often expresses highly positive views of China's historical heritage, the diligence and wisdom of Chinese people, 
draws certain parallels between the two countries as having rich and ancient civilizations and emphasizes centuries long cultural exchanges between the two countries (Thairath, 2013). While emphasizing the close friendship between the two countries, the great progress that China has made and the need for Thailand to learn from China's experience, the Princess's speeches are mostly general and do not elaborate on the exact aspects of China's experience or its current political-economic model that should be introduced to Thailand (for example, Princess Sirindhorn, 2009). Her books are structured like travelogues and are mostly devoted to depicting the places she has visited while in China as well as the people she has met while there (for example, see Princess Sirindhorn, 1998).

While contributing to the creation of the positive image of China and a sense of affinity, neither the narrative advocated by the royal family nor the broader discourse on kinship, refer to any normative similarities between the two nations. Some observers however argued that the discourse on kinship has been accompanied by a gradual importation of the Chinese authoritarian model to Thailand, pointing to the premiership of Thaksin Shinawatra as the starting point of this process (Zawacki, 2017, p. 150).

Indeed, certain domestic and foreign policy developments during Thaksin's rule support this argument. Thaksin adopted the 'Asia for Asians' approach as the main pillar of Thailand's regional policy and during his rule Sino-Thai relations became significantly closer (McCargo \& Pathmanand, 2005, p. 53). It was under Thaksin's premiership that an FTA between the two countries was signed in 2003, and numerous regional and bilateral initiatives pushed the two countries closer together. In terms of domestic politics, Thaksin, whose rise was, ironically, largely the product of Thailand's democratization of the 1990s, did not hold democracy nor those that promoted it in high regard (Lynch, 2006, p. 78). His rule became increasingly authoritarian, leading to some observers referring to it as 'parliamentary dictatorship' (Nelson, 2011). Thaksin was also no doubt corrupt, using state's means to protect and advance personal and crony allies' business interests (Phongpaichit \& Baker, 2009, pp. 197-205.)

During Thaksin's rule, the positive image of China and the view of the latter's importance started to gain prominence on all levels of the Thai society (Zawacki, 2017, p. 132). However, the argument that along with other Chinese products, 'Bangkok has imported Chinese authoritarianism' (Zawacki, 2017, p. 150) which construes the growth of China's positive image and Thaksin's authoritarianism as essentially part of the same phenomenon seems to be exaggerated.

It is indeed possible that China came to serve as an 'authoritarian center of gravity' for Thaksin and his successors, exerting certain influence on its mode of governance (Raymond, 2019, p. 347). However, from a different 
perspective, Thaksin's authoritarianism can be plausibly interpreted as a revival of a decades old Thai ideology under which economic progress was associated with strong state (Phongpaichit \& Baker, 2009, pp. 268-277). It should also be remembered that while Thaksin was indeed becoming increasingly authoritarian, he was also very much a reformer who challenged traditional institutions, fought against the old elites, and enabled the emergence of new actors on Thai political arena (Hewison, 2010). Moreover, Thaksin explicitly rejected any ideology, arguing that in postCold War era, politics were about proper management aimed at solving the country's problems. When seeking to legitimize a certain policy, Thaksin, rather skillfully, made use of a whole range of ideas that suited his purpose at that moment to convince his audience. When arguing that the essence of the social contract theory was the sacrifice of individual freedom for the general good, he was quoting Rousseau. When justifying his harsh treatment of the opposition, Thaksin referred to the teachings of Buddhadasaone of the most influential Thai Buddhist philosophers of the 20th century (Phongpaichit \& Baker, 2009, pp. 135-138). Thus, rather than a manifestation of a new identity or evidence of China's productive power, the discourse about kinship with China, should be seen more as a framing device used by Thaksin to legitimize his policies domestically and to appeal to his Chinese counterparts (McCargo \& Pathmanand, 2005, p. 183).

After the September 2006 military coup that ousted Thaksin, Thailand went through almost a decade of political instability. In May 2014, the military staged another coup, aimed at ending Thaksin's family's influence on Thai politics. The rule of National Council for Peace and Order created by the junta, formally ended in 2017 but the new constitution enabled the junta to continue to rule in the form of a 'democratic dictatorship' after the 2019 elections. Notwithstanding the fact that China related corruption deals were part of the accusations against Yingluck, Thaksin's sister who occupied the Prime-Ministerial post just before the coup, the junta fostered even closer relations with China than the previous governments (Storey, 2015).

The Chinese model of continuing economic growth combined with suppression of individual freedoms has been found increasingly appealing by the Thai military (Tejapira, 2020, pp. 21-22). Now, calls for embracing the Chinese model were voiced openly by the Thai leadership. In 2016, the Thai press reported that during a Cabinet meeting, Prime Minister and the leader of the junta, General Prayut Chan-o-cha, recommended to his fellow Cabinet members to read Xi Jinping's The Governance of China, as both countries going through a similar period of reforms (Matichon, 2016). In 2018, Deputy Prime Minister Somkid Jatusripitak in an address to ThailandChina Business Forum, explicitly stated that Thailand can learn from the Chinese model (Xinhua, 2018). 
Like in the case of Thaksin, it is possible that the Chinese model has exercised certain influence on General Prayut and associates but there is no definitive evidence to suggest that this indeed has been the case. In interviews with the domestic and foreign press, Prayut emphasizes his patriotism, makes references to Thai culture but never mentions China's influence on his political decisions (e.g. Campbell, 2018). Indeed, his list of ten recommended books includes The Governance of China but also the Animal Farm and several volumes on business management (The Standard, 2019). The emphasis on order, economic development and close relationship between the people and the government in the exerts from the semi-autobiographical volume published by Prayut's party in 2019 for internal circulation (Komchadluek, 2019; Prachachat, 2019), suggest certain similarities in Prayut's and Xi's worldviews. Similar ideas however can be found probably in writings by any other authoritarian ruler. Thus, it seems that rather than being influenced by the Chinese model, the 2014 coup as well as the subsequent political transformations implemented by the junta were driven by the desire to safeguard the political dominance of the royalist elites that include the military (Kongkirati \& Kanchoochat, 2018). Just like earlier governments therefore, the references to the Chinese model, are probably more of a framing tool used to justify and legitimize the new rulers' domestic policies and to appeal to China (Tungkeunkunt \& Phuphakdi, 2018) rather than evidence of its productive effect. In the words of Tejapira (2020, p. 23), the Chinese model serves as 'an ideological shield provided by an alternative type of legitimacy' for the junta that has continuously suffered from legitimacy deficit.

We can conclude therefore, that China's rise has not produced new identities among the Thai elites but rather, at its most, enhanced existing ones. In forging its China related policy, Thailand has traditionally adhered to the principle of 'bamboo bending in the wind' meaning flexibility and careful balancing in its relations with the major powers in pursuit of pragmatic national interests. China's rise and the relative decline of the US has forced the Thai policy to lean more often towards China, but this has been done in pursuit of pragmatic interests (Busbarat, 2016b). The discourse on kinship and the praises of the Chinese model that accompanied this leaning, should be understood as framing instruments aimed at appealing to the Chinese leadership and at the same time, enhancing the regime's domestic legitimacy.

\section{South Korea}

Since early 2010s, numerous Korea watchers have argued that China's rise has brought back the historical Confucian tributary system values to the fore of bilateral relations and that South Korea is willingly embracing China 
as the new regional hegemon (Chung \& Kim, 2016; Lee \& Paik, 2018). Earlier, similar idea was voiced by David Kang (2007) who suggested that the historical memory of friendly but hierarchical relations with China are integral to Korean national identity and play an important role in shaping bilateral relations. Jin Kai (2016) referred to this element of Korean national identity as part of a 'cognitive entanglement' espoused by Korean policymakers in which they are torn between two conflicting desires; one to uphold Korea's ties with the US, and the other to join's China in the construction of new order in East Asia, or 'even to return to the long-gone tributary system as an inferior small neighbor'. In other words, this view of bilateral relations suggests that the rise of China has had a productive effect on Korean national identity by reactivating and bringing to fore the 'junior partner' or 'vassal' element.

Such arguments were particularly often heard during the early years of Park Geun-hye presidency (2013-2017) (Chung \& Kim, 2016). From her early days in the office, Park indeed worked hard to improve state-level relations as well as to establish good personal relations with China's leader $\mathrm{Xi}$ Jinping. As a result, the two countries went through a relatively short period of very close relations which ended in mid-2016, after South Korea's decision to deploy THAAD anti-missile defense system. During the first three years of Park' presidency, she held six summit meetings with Xi and travelled to Beijing three times. In 2015, as a comment on the state of bilateral relations, $\mathrm{Xi}$ declared that the Korea-China relationship has become 'the best-ever national relationship in history' (Hartcher, 2016). During this period, the two countries also boosted their alignment based on collective memory of colonization and occupation by Imperial Japan. This boost was a result of several symbolic measures undertaken by both leaders such as the establishment of memorials related to Korean anti-colonial struggle in China and Park Geun-hye's attendance of China's Victory Day (in the war against Japan) celebration on September 3, 2015.

Before proceeding further, it should be noted that neither the centrality of Japan's colonialism in Korea's national identity nor the alignment with China in issues related to colonization/occupation by Japan are new. For decades, the historical memory of colonization by Japan and the related sense of victimhood have been one of the central elements in Korea's national identity. The convergence between the two countries' positions on related issues can also be traced back to at least early 1980s (Nozaki, 2002). Therefore, while acknowledging the convergence of China and South Korea's identities based on historical memory and the 'othering' of Japan, it is the evidence of 'junior partner' identity based on common values of Confucianism in the Korean elite discourse that can provide support for productive effects of China's rise. 
A search in official documents and speeches by key policy makers during Park's presidency however has not yielded any evidence to support such an argument. Korean official documents published during this period, such as the annual Diplomatic White Paper, continue to emphasize the 'common values' of Korea and the US. When depicting relations with China, they note the importance of the strategic cooperative partnership between the two countries but do not carry any references to common values (e.g. MOFA ROK, 2015). The working report submitted by Korea's Ministry of Foreign Affairs to President Park few weeks after her inauguration, which outlined the main issues and goals in Korea's foreign relations, noted the need to balance Korea-US alliance with its partnership with China but neither explicitly nor implicitly referred to any common values or identities shared by the two countries (MOFA ROK, 2013). Likewise, the Joint Statement on Korea-China Future Vision adopted on June 27, 2013 mentioned shared interests and referred to the two countries' working together towards peace on the Korean Peninsula and beyond, as well as other instances of cooperation, but carried no references to any normative commonalties (Kwak, 2013). To the contrary, during Park's presidency, South Korean politicians continued to emphasize their country's adherence to the principles of democracy and their belief in its universal applicability, including the AsiaPacific region (e.g. Yun, 2014). A search on Korea's National Assembly parliamentary interpolations' database during the 19th (2012-2016) and the 20th (2016-2020) assemblies with keywords 'Korea China common values', 'Korea China Confucianism', 'Korea China culture' did not bring any results relevant for this study.

Quotes from Chinese classics and references to cultural similarity and long history of cultural exchanges between the two nations are indeed occasionally made by Korean officials in their discussions with the Chinese officials, the public, and the media. Rather than expressions of a 'junior partner' or a 'vassal' identity, however, these should be understood as framing tools aimed at creating certain familiarity and commonality between the Korean 'self' and the Chinese 'other' while delivering a certain message. For example, when talking to the Chinese media, South Korea's ambassador to China, Noh Young-min (2017), used a quote from Confucius to explain the existing difficulties in two countries' relations and the need to start from relatively minor issues to achieve an overall improvement. Park Geunhye herself extensively used quotes from Chinese classics at a speech she gave at Tsinghua University during her June 2013 'trip of heart and trust' to Beijing. She also emphasized the centuries long history of interactions between the two peoples and the cultural familiarity the Korean people, including herself, experience during their visits to China. Park (2013) also mentioned the 'Chinese dream' and noted that Koreans are also pursuing 
the Korean dream. She did not however draw any parallels between the two nations, except for the vague 'pursuit of happiness' by both peoples. Such statements can hardly be interpreted as something more than a rhetorical device commonly used by politicians and diplomats aimed at showing respect and familiarity with the audience's culture. Moreover, it could be argued that precisely the lack of common values and identities makes historical and cultural references so important when Korean leaders attempt to establish certain proximity with the Chinese audience.

To summarize, the elite discourse in South Korea does not show any productive effects of China's rise. The proponents of the 'vassal' or the 'junior partner' identity seem to engage is a tautological exercise by deriving their evidence solely from South Korea's policy towards China. However, South Korea's proactive search for improved ties with China can be more persuasively explained through either the realist or the liberal lens (Chung, 2007, pp. 16-17). As numerous Korean commentators suggest, relations with China are important to Korea for both economic reasons and China's vital role in stabilizing inter-Korean relations (e.g. Lee, 2012). It is indeed a difficult choice for Korea when pressured to take sides between the US and China and the pursuit of the 'reliance on US for security and on China for economy' model is becoming increasingly difficult. This difficulty however, is not a product of shared norms or identities but is based in a practical fear of retaliation, from, what Victor Cha referred to as China's 'predatory liberalism' (Cha, 2020; also see Woo, 2020).

\section{General public}

There is an abundance of public opinion polls tracing the dynamics of public attitudes towards China in South Korea and, to a lesser extent, in Thailand. In a nutshell, these surveys show that people in both countries see China as an important regional and global payer which exercises growing influence in the region. The favorable/unfavorable attitudes towards China in South Korea have fluctuated greatly, depending on the state of bilateral relations. In the 1990s and early 2000s, these attitudes were mostly favorable, but during the Goguryeo-related historical controversy in mid 2000s, and since the THAAD related tensions from 2017 onwards, the unfavorable view gained dominance (Cha, 2017; Chu, Kang, \& Huang, 2015; Chung, 2012).

Polls related to Thai public perceptions are rather scarce but those that exist, suggest that during the past two decades, the Thais have generally maintained a favorable view of China and see it as an important and positive external influence on their country and the region more broadly (Chu et al., 2015; Pew Research Center, 2014; US Embassy polls cited in Zawacki, 
2017). These polls of course do not capture the whole picture as certain groups in the society, in particularly the military, express certain concerns about China's growing military capabilities (Blaxland \& Raymond, 2017). There also have been instances of dissatisfaction with the omnipresence of Chinese tourists and their behavior and, more importantly, dissent against the Thai government's close relations with China and the Chinese model of governance. The most important such instance of dissent has been the socalled Milk Tea Alliance that brought together online activists in Hong Kong, Taiwan and Thailand and inspired the ongoing pro-democracy protests which have drawn tens of thousands of mostly young protesters to the streets of Bangkok. These protests have been interpreted by some pundits as a rejection of the authoritarian model represented by China (Barron, 2020). While no doubt important for understanding the societal trends, the demographic make-up of the protesters, their concentration in Bangkok and general lack of references to China in their demands concerned mostly with domestic politics, do not allow us to draw any overarching conclusions regarding the broader effects of the Chinese model on the Thai society.

The above-mentioned polls on the other hand, are do doubt more representative of the broader population. However, they consist of general questions about feeling towards a certain country or its influence, and do not offer any evidence regarding the ideational impact of the Chinese model (Holyk, 2011, p. 227). A change from a positive to a negative (or vice versa) attitude towards a certain country can result from numerous factors, some identity related but some not. Zhang (2014) for example, shows that in Asia, positive attitudes towards China have no relationship with preferences for democracy, and affinity for China's influence has only a negligible impact on the respondents' desire to adopt the Chinese model in their country. The only large-scale poll that asked the respondents detailed questions about China's political model and values was the Chicago Council on Global Affairs' 'Soft Power in Asia' survey (Whitney \& Shambaugh, 2008). Unfortunately, this survey was conducted only once in 2008 and thus does not allow us to trace any possible changes that occurred in the public attitudes over the last decade or so.

There are other sets of large surveys however, which do not engage specifically in gauging public attitudes towards the Chinese model but nevertheless can offer some hints regarding possible identity shifts. As noted earlier, the productive power potential of China resides in its model of a highly centralized, economically successful state in which the individual rights are sacrificed for the benefits of, what the state defines as, a public interest. Not surprisingly the values implied in this model generally correspond to authoritarian values; values that emphasize security and conformity, support for the subordination of the individual to collective authority, 
preference for order, the belief that outcomes should be achieved by force if necessary, and obedience towards leaders and authorities (Ballard-Rosa, Jensen, \& Scheve, 2018; Duckitt, 1989; Duckitt, Bizumic, Krauss, \& Heled, 2010; Dunwoody \& Funke, 2016). As such, changes in public attitudes towards such values can offer some hints regarding the productive effects of rising China. No doubt, such changes in public attitudes are brought about by multiple factors, with domestic political, economic, and social conditions being probably more important than external influences. At the same time, if China's rise had a productive effect on national identities, we can expect a certain shift towards greater acceptance of authoritarian values among the Korean and the Thai public.

To trace such shifts, I used data provided by the Asian Barometer and World Values Surveys (Inglehart et al., 2014; Haerpfer et al., 2020) to conduct two-sample t-tests for identical questions included in surveys conducted in both countries over the last two decades. My hypothesis is that if identity shifts did occur, there would be a statistically significant difference of means in public attitudes towards authoritarian values. In the case of Asian Barometer, I tested Wave 1 and the latest available results of Wave 4 for surveys conducted in South Korea in 2003 and 2015, and in Thailand in 2001 and 2014. For World Values Survey, I tested Wave 5 and 6 results (South Korea 2005 and 2010, Thailand 2007 and 2013), but also the results of Wave 5 and the most recent Wave 7 survey conducted in both countries in 2018.

In both surveys, I extracted questions that tap into respondents' attitudes to authoritarian/democratic values. The total of ten questions were selected from the Asia Barometer survey (Table 1) with eight coming from the 'Authoritarian/Democratic Values' section and additional two questions of direct relevance to these values which appeared in other sections. From World Values Survey (Table 2), I extracted four questions from 'Political Culture\& Political Regimes' section and two additional questions from other sections. Most of the questions use the Likert scale ( $1=$ strongly agree, $4=$ strongly disagree). One question in each of the surveys ask the respondents to locate their response on a scale of 1 to 10. The question from World Values Survey that asks the respondents about their attitude towards greater respect for authority uses the $1=$ a good thing, $3=$ a bad thing, $2=$ don't mind scale.

It should be noted that Waves 3 and 4 of Asian Barometer came to include China related questions with one of them asking the respondents which country's model should be adopted in their country including China among the list of possible models (other models were US, Japan, India, Singapore and 'our own model'). The results show that only a small percentage of respondents chose China as the model to follow ( $8 \%$ and $10 \%$ 
Table 1. Asian Barometer questions.

As you know, there are some people in our country who would like to change the way in which our country is governed. We would like to know what you think of their views. For each statement, would you say you STRONGLY AGREE, SOMEWHAT AGREE, SOMEWHAT DISAGREE, or STRONGLY DISAGREE?

Q1. Government leaders are like the head of a family; we should all follow their decisions.

Q2. The government should decide whether certain ideas should be allowed to be discussed in society.

Q3. Harmony of the community will be disrupted if people organize lots of groups.

Q4. When judges decide important cases, they should accept the view of the executive branch.

Q5. If the government is constantly checked by the legislature, it cannot possibly accomplish great things.

Q6. If we have political leaders who are morally upright, we can let them decide everything.

Q7. If people have too many different ways of thinking, society will be chaotic.

Q8. When the country is facing a difficult situation, it is ok for the government to disregard the law in order to deal with the situation.

Strongly Agree $=1$, Somewhat agree $=2$, Somewhat disagree $=3$, Strongly disagree $=4$

Q9. If ' 1 ' means that democracy is completely unsuitable for your country today and ' 10 ' means that it is completely suitable, where would you place our country today? (Code one number between 1 and 10)

Q10. If you had to choose between democracy and economic development, which would you say is more important?

Economic development is definitely more important 1 Somewhat more important 2

Democracy is somewhat more important 3 Definitely more important 4

$A=$ trend towards greater acceptance of authoritarian values

$\mathrm{D}=$ trend toward greater acceptance of democratic values

*=Statistically significant difference

in South Korea, and 13\% and 19\% in Thailand) but similarly to other general questions about attitudes towards China, being rather general and not specifying the exact meaning of Chinese model, the responses to this question can hardly be used to evaluate identity shifts.

Asian Barometer results (Table 3) show mixed results with changes in public attitudes happening in both directions. However, if we focus only on statistically significant trends (highlighted in yellow), we can conclude that from early 2000s to mid-2010s, public attitudes in both countries shifted slightly in the direction of democratic values and away from authoritarian ones. These conclusions are confirmed by the results of a t-test for World Values Survey Waves 5 and 6 (Table 4). In South Korea, the public attitudes remained generally stable, while in Thailand there has been a statistically significant shift in the direction of democracy for most of the questions.

A t-test for Waves 5 and 7 however suggests a reverse trend in both countries. For both South Korea and Thailand, the results show a greater tolerance towards having a strong leader not constrained by either elections or the parliament and having the army rule. In Thailand there is also a growing tolerance towards political decision-making process led by experts rather than the government and a greater respect for authority. The results also show a statistically significant decrease in support for a democratic political system in Korea and a similar decrease in the importance people assign to living in a democratic country in both Korea and Thailand (Table 5). 
Table 2. World Values Survey questions.

I'm going to describe various types of political systems and ask what you think about each as a way of governing this country. For each one, would you say it is a very good, fairly good, fairly bad or very bad way of governing this country?

Q1. Having a strong leader who does not have to bother with parliament and elections

Q2. Having experts, not government, make decisions according to what they think is best for the country

Q3. Having the army rule

Q4. Having a democratic political system

Very good $=1$, Fairly good $=2$, Fairly bad $=3$, Very bad $=4$

Q5. How important is it for you to live in a country that is governed democratically? On this scale where 1 means it is 'not at all important' and 10 means 'absolutely important' what position would you choose? (Code one number between 1 and 10)

Q6. I'm going to read out a list of various changes in our way of life that might take place in the near future. Please tell me for each one, if it were to happen, whether you think it would be a good thing (1), a bad thing (3), or don't you mind (2)? Greater respect for authority.

$A=$ trend towards greater acceptance of authoritarian values

$\mathrm{D}=$ trend toward greater acceptance of democratic values

*=Statistically significant difference

Table 3. Asian Barometer difference of means t-test Waves 1 and 4.

\begin{tabular}{|c|c|c|c|c|c|c|c|c|c|c|}
\hline & \multicolumn{5}{|c|}{ South Korea } & \multicolumn{5}{|c|}{ Thailand } \\
\hline & $\begin{array}{l}\text { Mean } \\
2003\end{array}$ & $\begin{array}{c}\text { Mean } \\
2015\end{array}$ & $\begin{array}{c}\text { Mean } \\
\text { Difference }\end{array}$ & Trend & $\begin{array}{c}\text { T-test } \\
(P)\end{array}$ & $\begin{array}{c}\text { Mean } \\
2001\end{array}$ & $\begin{array}{c}\text { Mean } \\
2014\end{array}$ & $\begin{array}{c}\text { Mean } \\
\text { Difference }\end{array}$ & Trend & $\begin{array}{l}\text { T-test } \\
(P)\end{array}$ \\
\hline Q1 & 2.601 & 2.7793 & 0.178 & $D$ & $<0.0001^{*}$ & 2.3125 & 2.5689 & 0.256 & $\mathrm{D}$ & $<0.0001^{*}$ \\
\hline Q2 & 2.7148 & 2.6583 & -0.056 & $A$ & 0.0662 & 2.4856 & 2.4383 & -0.047 & $A$ & 0.2444 \\
\hline Q3 & 2.7677 & 2.7671 & -0.001 & $A$ & 0.9843 & 1.761 & 1.7655 & 0.005 & $D$ & 0.8948 \\
\hline Q4 & 2.8872 & 2.8848 & -.002 & $A$ & 0.9361 & 2.3359 & 2.3382 & 0.002 & $\mathrm{D}$ & 0.9532 \\
\hline Q5 & 2.605 & 2.6525 & 0.047 & $D$ & 0.1145 & 2.4483 & 2.4255 & -0.063 & $A$ & 0.0977 \\
\hline Q6 & 2.279 & 2.4139 & 0.135 & $D$ & $<0.0001^{*}$ & 1.9499 & 2.0835 & 0.134 & $D$ & 0.0001 \\
\hline Q7 & 2.5958 & 2.6582 & 0.062 & $\mathrm{D}$ & 0.0392 & 1.9505 & 1.8394 & -0.111 & $A$ & 0.0017 \\
\hline Q8 & 3.0273 & 2.9304 & -0.097 & $A$ & 0.0011 & 2.5515 & 2.4081 & -0.143 & $A$ & 0.0002 \\
\hline Q9 & 6.8576 & 7.2353 & 0.378 & $\mathrm{D}$ & $<0.0001^{*}$ & 8.7486 & 7.5815 & -1.167 & $A$ & $<0.0001^{*}$ \\
\hline Q10 & 1.9187 & 2.031 & 0.112 & D & 0.0018 & 1.8925 & 2.1063 & 0.214 & $D$ & $<0.0001^{*}$ \\
\hline
\end{tabular}

*Statistically significant difference.

Table 4. World Values Survey difference of means t-test Waves $5 \& 6$.

\begin{tabular}{|c|c|c|c|c|c|c|c|c|c|c|}
\hline & \multicolumn{5}{|c|}{ South Korea } & \multicolumn{5}{|c|}{ Thailand } \\
\hline & $\begin{array}{l}\text { Mean } \\
2005\end{array}$ & $\begin{array}{c}\text { Mean } \\
2010\end{array}$ & $\begin{array}{c}\text { Mean } \\
\text { Difference }\end{array}$ & Trend & $\begin{array}{l}\text { T-test } \\
(\mathrm{P})\end{array}$ & $\begin{array}{c}\text { Mean } \\
2007\end{array}$ & $\begin{array}{l}\text { Mean } \\
2013\end{array}$ & $\begin{array}{c}\text { Mean } \\
\text { Difference }\end{array}$ & Trend & $\begin{array}{c}\text { T-test } \\
(P)\end{array}$ \\
\hline Q1 & 2.575 & 2.5365 & -0.039 & $A$ & 0.2600 & 2.1589 & 2.8946 & 0.736 & D & $<0.0001^{*}$ \\
\hline Q2 & 2.4825 & 2.4719 & -0.011 & A & 0.7085 & 2.32 & 2.8509 & 0.531 & $\mathrm{D}$ & $<0.0001^{*}$ \\
\hline Q3 & 3.4192 & 3.4723 & 0.053 & D & 0.0371 & 2.45 & 2.842 & 0.392 & $\mathrm{D}$ & $<0.0001^{*}$ \\
\hline Q4 & 2.0167 & 2.0705 & 0.054 & $A$ & 0.0841 & 1.6287 & 1.4142 & -0.215 & $\mathrm{D}$ & $<0.0001^{*}$ \\
\hline Q5 & 8.5708 & 8.462 & -0.109 & A & 0.1037 & 8.208 & 8.426 & 0.218 & $\mathrm{D}$ & 0.0011 \\
\hline Q6 & 2.159 & 2.1444 & 0.015 & A & 0.641 & 2.066 & 1.912 & 0.154 & A & $<0.0001^{*}$ \\
\hline
\end{tabular}

*Statistically significant difference.

To summarize, the results of Asian Barometer and World Values surveys show that between early 2000s and mid-2010s, the period when both countries' relations with China became increasingly thicker and China's rise became one of the key topics in regional and worldwide debates, public attitudes towards political values in both countries remained relatively stable. During recent years however, when the hopes of China's socialization 
Table 5. World Values Survey difference of means t-test Waves 5 \& 7.

\begin{tabular}{|c|c|c|c|c|c|c|c|c|c|c|}
\hline & \multicolumn{5}{|c|}{ South Korea } & \multicolumn{5}{|c|}{ Thailand } \\
\hline & $\begin{array}{l}\text { Mean } \\
2005\end{array}$ & $\begin{array}{c}\text { Mean } \\
2018\end{array}$ & $\begin{array}{c}\text { Mean } \\
\text { Difference }\end{array}$ & Trend & $\begin{array}{l}\text { T-test } \\
(\mathrm{P})\end{array}$ & $\begin{array}{l}\text { Mean } \\
2007\end{array}$ & $\begin{array}{l}\text { Mean } \\
2018\end{array}$ & $\begin{array}{c}\text { Mean } \\
\text { Difference }\end{array}$ & Trend & $\begin{array}{l}\text { T-test } \\
(\mathrm{P})\end{array}$ \\
\hline$\overline{\mathrm{Q} 1}$ & 2.575 & 2.2418 & -0.333 & A & $<0.0001^{*}$ & 2.1589 & 1.6144 & -0.545 & $A$ & $<0.0001^{*}$ \\
\hline Q2 & 2.4825 & 2.4514 & -0.031 & A & 0.2972 & 2.32 & 2.1354 & -0.185 & A & $<0.0001^{*}$ \\
\hline Q3 & 3.4192 & 3.2602 & -0.159 & A & $<0.0001^{*}$ & 2.45 & 2.2989 & -0.151 & A & $<0.0001^{*}$ \\
\hline Q4 & 2.0167 & 2.1639 & 0.147 & A & $<0.0001^{*}$ & 1.6283 & 1.6469 & 0.019 & A & 0.4568 \\
\hline Q5 & 8.5708 & 7.9004 & -0.670 & A & $<0.0001^{*}$ & 8.208 & 7.6927 & -0.515 & A & $<0.0001^{*}$ \\
\hline Q6 & 2.1592 & 2.2291 & -.00699 & A & 0.0271 & 2.0655 & 2.299 & 0.234 & A & $<0.0001^{*}$ \\
\hline
\end{tabular}

*Statistically significant difference.

into the liberal order have diminished and its rise is increasingly seen not only as an economic but also as an ideological challenge, the public in both countries shows increasing acceptance of authoritarian values.

\section{Conclusion}

This paper sought to explore the productive effects of China's rise on national identities in South Korea and Thailand. The analysis of policy elites discourse suggests that regardless of the fundamental differences in the political systems of the two countries, the changes in material relations of power with China, did not transform the political norms that constitute their collective identities. The narratives on kinship and close historical and cultural ties are used instrumentally by Thai and South Korean policymakers to legitimize their rule domestically in the case of the former, and to appeal to the Chinese audience in case of the latter.

On the other hand, analysis of public opinion surveys suggest that compared to early 2000s, people in both countries find authoritarian values more acceptable. There are obvious limitations to the conclusions that can be drawn from the surveys used here as well as the tests conducted. A qualitative analysis of other locales of social knowledge such as newspapers or popular literature for example, may reveal discursive shifts that either confirm or contradict the results of these surveys. National identity is indeed an elusive concept. Focus on different texts and change in methods can result is diverging or even contradictory conclusions. In terms of the tests conducted, the number of questions chosen was rather limited, and a more sophisticated modelling or a longitudinal study is needed to measure the precise shifts in public attitudes. Moreover, the role of domestic factors in instigating such shifts is not to be ignored. The growing tolerance towards authoritarian values in Thailand could be traced to the people's memory of the political unrest that paralyzed the country in the first half of the 2010s, as well as a conscious or unconscious fear of retributions from the ruling junta when answering the questions. In the case of South Korea, 
the domestic-focused explanation is more complicated as the Wave 7 survey was conducted only a year after the 'democratic miracle' that ousted President Park Geun-hye and during the presidency of the popular, former human rights lawyer, Moon Jae-in. Economic problems, growing unemployment and rising home prices could be possibly considered as domestic factors that induced such change. At the same time, these shifts in Thailand and South Korea can be attributed to a global trend of decreasing support for democracy and rising dissatisfaction with the ways democratic institutions work (Diamond, 2015; Wike, Silver, \& Castillo, 2019). As such, it is difficult to make an argument for direct causality between these shifts in public attitudes and China's rise.

These caveats aside however, we cannot ignore the possibility that the relationship between the rise of China on one hand, and the shift towards authoritarian values in South Korea and Thailand on the other, is not simply coincidental. Diamond (2019) for example, lists 'an ambitious and rising China' as one of the causes behind the global crisis of democracy. Thus, China's authoritarian model which became increasingly vivid from mid2010s onwards, can be regarded as one of the factors which, at the very least, indirectly exercised a certain productive effect on national identity and political norms that constitute it in both countries. If this indeed is the case and the trend towards greater acceptance of authoritarian values is to continue, we can conclude that the ideological challenge of the Chinese model should be taken seriously by proponents of democracy in the AsiaPacific region and beyond.

\section{Notes}

1. The historical dispute over the ancient kingdom of Goguryeo did cause some tensions in China-South Korea relations is the early 2000s, but the dispute was quickly subdued as a result of an effort of political elites in both countries (for a detailed analysis see Chung 2009.)

\section{Acknowledgements}

This article uses data kindly provided by the World Values Survey Project and Asian Barometer Project which was co-directed by Profs. Fu Hu and Yun-han Chu and received major funding support from Taiwan's Ministry of Education, Academia Sinica and National Taiwan University. The Asian Barometer Project Office (www.asianbarometer.org) is solely responsible for the data distribution. The author appreciates the assistance in providing data by the institutes and individuals aforementioned. I am very grateful to my colleagues Assoc. Prof. Jana von Stein (ANU) and Dr. Matthew Castle (VUW) for their generous help in designing and conducting the quantitative analysis of the surveys' data. The views expressed herein are the author's own. I also thank Paweenuch Wannapak and Whetani Wirunsri for 
their research assistance with this project and the two anonymous reviewers for valuable insight and suggestions.

\section{Disclosure statement}

No potential conflict of interest was reported by the author(s).

\section{Funding}

Research conducted for this project was funded by Faculty Research Grant provided by my home institution. I also want to thank the Slavic-Eurasian Research Center at Hokkaido University for hosting me as a Visiting Researcher while working on this project.

\section{Notes on contributor}

Alexander Bukh is an Associate Professor (Reader) in International Relations at Victoria University of Wellington, New Zealand. Alexander has published numerous articles on international relations in Northeast Asia. He is the author of Japan's Identity and Foreign Policy: Russia as Japan's "Other" (Routledge 2009) and These Islands Are Ours: The Social Construction of Territorial Disputes in Northeast Asia (Stanford University Press 2020).

\section{References}

Aiyara, T. (2020). tai keizai ni okeru chuugoku no eikyouu [China's influence in Thai economy]. Kokusai Bōeki to Toshi, 120, 76-101.

Anderlini, J., \& Smyth, J. (2017, December 19). West grows wary of China's influence game. Financial Times. Retrieved from https://www.ft.com/content/d3ac306ae188-11e7-8f9f-de1c2175f5ce

Ballard-Rosa, C., Jensen, A., \& Scheve, K. (2018). Economic decline, social identity, and authoritarian values in the United States, Paper presented at the American Political Science Association, Boston.

Bangkok Post. (2020, January 24). Foreign tourist arrivals up 4\% in 2019. Retrieved from https://www.bangkokpost.com/business/1842844/foreign-tourist-arrivals-up4-in-2019

Barnett, M., \& Duvall, R. (2005). Power in international politics. International Organization, 59(01), 39-75. doi:10.1017/S0020818305050010

Barron, L. (2020, October 28). 'We Share the Ideals of Democracy'. How the milk tea alliance is brewing solidarity among activists in Asia and beyond. Time Magazine. Retrieved from https://time.com/5904114/milk-tea-alliance/

Berger, P., \& Luckmann, T. ([1966] 1980). The social construction of reality. New York: Irvington.

Blaxland, J., \& Raymond, G. (2017). Tipping the balance in Southeast Asia? Thailand, the United States and China. Canberra: Strategic and Defence Studies Centre, ANU.

Bong, Y. (2016). The US-South Korea alliance: Local, regional, and global dimensions. Asian Politics \& Policy, 8(1), 39-49. 
Boontarahan, J. (2015, July 20). Sankwamsampantai-jeen bhooprommitphaph 'sentang saimai' (Engaging Thai-China relationships on the friendship path of the 'Silk Road'). Retrieved from https://www.dailynews.co.th/article/335874

Bourdieu, P. (1979). Symbolic power. Critique of Anthropology, 4(13-14), 77-85. doi: 10.1177/0308275X7900401307

Bukh, A. (2007). Japan's history textbooks debate: National identity in narratives of victimhood and victimization. Asian Survey, 47(5), 683-704. doi:10.1525/as.2007. 47.5.683

Bukh, A. (2010). Japan's national identity and foreign policy: Russia as Japan's' other. Oxon: Routledge.

Busbarat, P. (2016a). 'Family' making in Sino-Thai Relations. Kyoto Review of Southeast Asia. Retrieved from https://kyotoreview.org/yav/family-sino-thairelations/

Busbarat, P. (2016b). "Bamboo swirling in the wind": Thailand's foreign policy imbalance between China and the United States. Contemporary Southeast Asia, 38(2), 233-257. doi:10.1355/cs38-2c

Campbell, C. (2018). Thailand PM Prayuth Chan-ocha on turning to China over the U.S. Time Magazine. Retrieved from https://time.com/5318224/exclusive-primeminister-prayuth-chan-ocha-thailand-interview/

Cha, J. (2017). The change of Korean perceptions toward China since 1992 normalization of the diplomatic relations. The Journal of Asiatic Studies, 60(2), 10-45.

Cha, V. (2020). Migugeun jiwon eobsi jungguge majseola yogu malaya [US shouldn't be asking to confront China without providing support]. Chosun Ilbo, 26(06).

Chachavalpongpun, P. (2011). The necessity of enemies in Thailand's troubled politics. Asian Survey, 51(6), 1019-1041. doi:10.1525/as.2011.51.6.1019

Chambers, M. R. (2005). 'The Chinese and the Thais are brothers': The evolution of the Sino-Thai friendship. Journal of Contemporary China, 14(45), 599-629. doi:10. 1080/10670560500205100

Chang, H. (2017, September 14). South Koreans worked a democratic miracle. Can they do it again? NY Times. Retrieved from https://www.nytimes.com/2017/09/14/ opinion/south-korea-social-mobility.html

Chantasasawat, B. (2006). Burgeoning Sino-Thai relations: Heightening cooperation, sustaining economic security. China: An International Journal, 4(1), 86-112.

Chearavanont, D. (2016). Faith in Deng Xiaoping, growth for CP Group, Asia Nikkei. Retrieved September 21, 2016, from https://asia.nikkei.com/Spotlight/MyPersonal-History/Dhanin-Chearavanont/Dhanin-Chearavanont-21-Faith-in-DengXiaoping-growth-for-CP-Group2

Checkel, J. (1999). Norms, institutions, and national identity in contemporary Europe. International Studies Quarterly, 43(1), 84-114. doi:10.1111/0020-8833.00112

Cheng-Chwee, K. (2008). The essence of hedging: Malaysia and Singapore's response to a rising China. Contemporary Southeast Asia, 30(2), 159-185. doi:10.1355/CS30-2A

Cheong, Y., \& Lee, C. (2011). Korea-China economic partnership: The third China rush. Korea's Economy, 2011(27), 84-96.

Cho, Y., \& Jeong, J. (2008). China's soft power: Discussions, resources, and prospects. Asian Survey, 48(3), 453-472. doi:10.1525/as.2008.48.3.453

Chu, Y., Kang, L., \& Huang, M. (2015). How East Asians view the rise of China. Journal of Contemporary China, 24(93), 398-420. doi:10.1080/10670564.2014.953810

Chung, J. (2007). Between Ally and partner: Korea-China relations and the United States. New York: Columbia University Press. 
Chung, J. (2009). China's 'Soft' clash with South Korea: The history war and beyond. Asian Survey, 49(3), 468-483. doi:10.1525/as.2009.49.3.468

Chung, J. (2012). Korean views of Korea-China relations: Evolving perceptions and upcoming challenges. Asian Perspective, 36(2), 219-236. doi:10.1353/apr.2012.0008

Chung, J., \& Kim, J. (2016). Is South Korea in China's orbit? Assessing Seoul's perceptions and policies. Asia Policy, 21(1), 123-146. doi:10.1353/asp.2016.0000

The Conservative Party Human Rights Commission. (2019). China's Confucius Institutes. Retrieved from http://www.conservativehumanrights.com/news/2019/ CPHRC_Confucius_Institutes_report_FEBRUARY_2019.pdf

Connors, M. K. (2007). Democracy and national identity in Thailand. Singapore: NIAS Press.

Diamond, L. (2015). Facing up to the democratic recession. Journal of Democracy, 26(1), 141-155. doi:10.1353/jod.2015.0009

Diamond, L. (2019, May 18). The global crisis of democracy. Wall Street Journal. Retrieved from https://www.wsj.com/articles/the-global-crisis-of-democracy11558105463

Dig Mandarin. (2020). Confucius Institutes around the world - 2020. Retrieved from https://www.digmandarin.com/confucius-institutes-around-the-world.html

Duckitt, J. (1989). Authoritarianism and group identification: A new view of an old construct. Political Psychology, 10(1), 63-84. doi:10.2307/3791588

Duckitt, J., Bizumic, B., Krauss, S. W., \& Heled, E. (2010). A tripartite approach to rightwing authoritarianism: The authoritarianism-conservatism-traditionalism model. Political Psychology, 31(5), 685-715. doi:10.1111/j.1467-9221.2010.00781.x

Dunwoody, P. T., \& Funke, F. (2016). The aggression-submission-conventionalism scale: Testing a new three factor measure of authoritarianism. Journal of Social and Political Psychology, 4(2), 571-600. doi:10.5964/jspp.v4i2.168

Fearon, J., \& Wendt, A. (2013). Rationalism v. constructivism: A sceptical view. In W. Carlsnaes, T. Risse, \& B. Simmons (Eds.), Handbook of International Relations(pp. 52-72). London: Sage.

Finnemore, M., \& Sikkink, K. (1998). International norm dynamics and political change. International Organization, 52(4), 887-917. doi:10.1162/002081898550789

Freedom House. (2020). Freedom in the World: Countries. Retrieved from https:// freedomhouse.org/countries/freedom-world/scores

Bates, G., \& Huang, Y. (2006). Sources and limits of Chinese 'soft power'. Survival, 48(2), 17-36. doi:10.1080/00396330600765377

Gustafsson, K. (2014). Is China's discursive power increasing? The 'power of the past' in Sino-Japanese relations. Asian Perspective, 38(3), 411-433. doi:10.1353/apr.2014. 0017

Haerpfer, C., Inglehart, R., Moreno, A., Welzel, C., Kizilova, K., Diez-Medrano, J., Lagos, M., Norris, P., Ponarin, E., Puranen, B., et al. eds. (2020). World values survey: Round seven - Country-pooled datafile. Madrid: JD Systems Institute \& WVSA Secretariat.

Hagström, L. (2015). The Sino-Japanese battle for soft power: Pitfalls and promises. Global Affairs, 1(2), 129-137. doi:10.1080/23340460.2015.990798

Hall, S. (2000). Who needs identity? In P. Du Gay, J. Evans, \& P. Redman (Eds.), Identity: A reader (pp. 15-30). London: Sage.

Hartcher, P. (2016). China the regional bully punishes defiance in Asia-Pacific. The Sydney Morning Herald. Sydney.

$\mathrm{He}, \mathrm{K}$. (2008). Institutional balancing in the Asia Pacific: Economic interdependence and China's rise. Oxon: Routledge. 
Hewison, K. (2010). Thaksin Shinawatra and the reshaping of Thai politics. Contemporary Politics, 16(2), 119-133. doi:10.1080/13569771003783810

Holyk, G. G. (2011). Paper tiger? Chinese soft power in East Asia. Political Science Quarterly, 126(2), 223-254. doi:10.1002/j.1538-165X.2011.tb00700.x

Hopf, T (2002) Social Construction of International Politics, Ithaca: Cornell University Press.

Huang, C. (2013). China's soft power in East Asia. NBR Special Report, 42, 1-19.

Huang, Y., \& Ding, S. (2006). Dragon's underbelly: An analysis of China's soft power. East Asia, 23(4), 22-44. doi:10.1007/BF03179658

Hughes, C. R. (2014). Confucius Institutes and the university: Distinguishing the political mission from the cultural. Issues and Studies, 50(4), 45-83.

Inglehart, R., C. Haerpfer, A. Moreno, C. Welzel, K. Kizilova, J. Diez-Medrano, M. Lagos, P. Norris, E. Ponarin \& B. Puranen, et al. (Eds.). (2014). World values survey. Madrid: JD Systems Institute.

Jepperson, R. L., Wendt, A., \& Katzenstein, P. J. (1996). Norms, identity, and culture in national security. In P. J. Katzenstein (Ed.), The culture of national security: Norms and identity in world politics (pp. 33-60). New York: Columbia University Press.

Kai, J. (2016). 3 Stages of Park Geun-hye's China Diplomacy, The Diplomat. Retrieved from https://thediplomat.com/2016/2012/2013-stages-of-park-geun-hyes-chinadiplomacy/).

Kang, D. (2007). China rising: Peace, power, and order in East Asia. New York: Columbia University Press.

Kim, J., Kim, Y., \& Lee, C. (2006). Trade, investment and economic interdependence between South Korea and China. Asian Economic Journal, 20(4), 379-392. doi:10. 1111/j.1467-8381.2006.00243.x

Kim, Y. (2011). Park Chung Hee's governing ideas: Impact on national consciousness and identity. In H.-A. K. Kim \& C. Sorensen (Eds.), Reassessing the Park Chung Hee Era, 1961-1979: Development, political thought, democracy \& cultural influence (pp. 66-84). Seattle: University of Washington Press.

Komchadluek (2019). 'Pracharat sarangchat' nangsue chak huachai thi chaotrak lungtu maidai ['Pracharath Building the Nation' a book from the heart that will make you love Uncle Tu]. Retrieved from https://www.komchadluek.net/news/politic/363562

Kongkirati, P., \& Kanchoochat, V. (2018). The Prayuth regime: Embedded military and hierarchical capitalism in Thailand. TRaNS: Trans-Regional and-National Studies of Southeast Asia, 6(2), 279-305.

Korea Tourism Organization. (2020). Visitor arrivals, Korean Departures, Int'l Tourism Receipts \& Expenditures. Retrieved from https://kto.visitkorea.or.kr/eng/ tourismStatics/keyFacts/KoreaMonthlyStatistics/

Kurlantzick, J. (2007). Charm offensive: How China's soft power is transforming the world. New Haven: Yale University Press.

Kwak, J. (2013). Hanjung milae bijeon gongdong seongmyeong [Joint Statement on Korea-China Future Vision]. Retrieved from https:/www.pressian.com/pages/ articles $/ 64915 ? \mathrm{no}=64915$

Lahtinen, A. (2015). China's soft power: Challenges of confucianism and Confucius Institutes. Journal of Comparative Asian Development, 14(2), 200-226. doi:10.1080/ 15339114.2015 .1059055

Lai, H., \& Lu, Y. (Eds.). (2012). China's soft power and international relations. Oxon: Routledge. 
Lee, J. (2017). Hedging strategies of the middle powers in East Asian security: The cases of South Korea and Malaysia. East Asia, 34(1), 23-37. doi:10.1007/s12140016-9264-8

Lee, S. (2012). Junggugui jilmun, 'han-jung saieseo hanmidongmaengeun mueosinga? [The China question: What is the meaning of ROK-US alliance in KoreaChina relations?] Retrieved from https://www.pressian.com/pages/articles/63482

Lee, S., \& Paik, W. (2018). Is South Korea leaning toward China? Questioning the contemporary application of the Japanese narrative about the historical Korean Peninsula-China linkage. Pacific Focus, 33(2), 237-259. doi:10.1111/pafo.12117

Lo, J., \& Pan, S. (2016). Confucius Institutes and China's soft power: Practices and paradoxes. Compare: A Journal of Comparative and International Education, 46(4), 512-532. doi:10.1080/03057925.2014.916185

Lynch, D. (2006). Rising China and Asian democratization. Stanford: Stanford University Press.

Mandelbaum, M. (2019). The new containment: Handling Russia, China, and Iran. Foreign Affairs, 98, 123-131.

Marks, S. (2005). 'Bravo, Brave Tiger of the East!' The Russo-Japanese war and the rise of nationalism in British Egypt and India. In J. Steinberg, B. Menning, D. Schimmelpenninck Van Der Oye, D. Wolff \& S. Yokote (Eds.), The Russo-Japanese war in global perspective: World war zero (pp. 609-628). Leiden: Brill.

Matichon. (2016). 'bik tu' naekhrom annangsue 'kanpokkhrong prathet jin' ('Big Tu' encourages the Cabinet to read the "Governance of China"). Matichon. Bangkok. 12.04.2016. Retrieved April 12, 2016, from https://www.matichon.co.th/politics/ news_103564.

McCargo, D., \& Pathmanand, U. (2005). The Thaksinization of Thailand. Singapore: NIAS Press.

McDougall, D. (2012). Responses to 'Rising China' in the East Asian Region: Soft balancing with accommodation. Journal of Contemporary China, 21(73), 1-17. doi:10. 1080/10670564.2012.627662

Ministry of Education PRC. (2019). Statistical report on international students in China for 2018. Retrieved from http://en.moe.gov.cn/en_IxIm/Spotlight/201904/ t20190418_378691.html

MOFA ROK. (2013). 'Gugminhaengbog, huimangui sae sidaeleul yeoneun sinloeoegyo' 2013 oegyobu eobmubogo (2013 Ministry of Foreign Affairs Report: 'Trust diplomacy, opening a new era of happiness and hope for the people'). Retrieved from http://www.korea.kr/special/policyFocusView.do?newsld= 148757819\&pkgld=49500566

MOFA ROK. (2015). 2015 diplomatic white paper. Seoul: MOFA.

MOFA Thailand. (2015). 40th anniversary of Thai-China diplomatic relationship. Bangkok: Ministry of Foreign Affairs of Thailand.

Narramore, T. (2008). China and Europe: Engagement, multipolarity and strategy. The Pacific Review, 21(1), 87-108. doi:10.1080/09512740701868930

Nelson, M. H. (2011). Thailand's legitimacy conflict between the Red Shirt Protesters and the Abhisit Government: Aspects of a complex political struggle. Sicherheit \& Frieden, 29(1), 14-18. doi:10.5771/0175-274x-2011-1-14

Neumann, I. B. (1996). Self and other in international relations. European Journal of International Relations, 2(2), 139-174. doi:10.1177/1354066196002002001

Noh, Y. (2017). Jung-gug eonlon inteobyu [Interview with Chinese media]. MOFA ROK. Retrieved from shorturl./aeiFO 
Nozaki, Y. (2002). Japanese politics and the history textbook controversy, 1982-2001. International Journal of Educational Research, 37(6-7), 603-622. doi:10.1016/S08830355(03)00053-3

Nye, J. S. (1990). Bound to lead: The changing nature of American power. New York: Basic Books.

Oguma, E. (2002). A genealogy of 'Japanese' self-images. Melbourne: Trans Pacific Press.

Park, G. (2013). Chinghwadae baggeunhye daetonglyeong yeonseol [Speech by President Park Geun-hye at Tsinghua University]. Kyunghyang Shinmun, June 29.

Panyarachun, A. (2011). Kanpoetsamphanthamaitri thaichin khong marawa khuekrit pramot [Kukrit Pramoj's Opening of Thai-China Friendship]. Hundred years since the birth of M.R. Kukrit Pramoj. Kukrit Institute, Bangkok. Retrieved from http:// www.anandp.in.th/th_speech/t_china2.html

Pew Research Center. (2014). China's image. Retrieved from https://www.pewresearch.org/global/2014/07/14/chapter-2-chinas-image/

Phanthong, A. (2020). Chin-thai chakratbannakan sukwampen phinong [China-Thai relations: From tribute to brotherhood], The People. Retrieved from https://thepeople.co/sino-thai-relations-tributary-system-brotherhood-discourse/

Phongpaichit, P., \& Baker, C. J. (2009). Thaksin. Chiang Mai: Silkworm Books.

Prachachat. (2019). Phopchon poet tuanangsue 'pracharat sarangchat' sathonchiwitkhwamkhit tuaton 'biktu' [NCCC launches the book 'Pracharat Building the Nation' that reflects the life, thinking and identity of 'Big Tu']. Retrieved from https://www.prachachat.net/politics/news-293780

Sirindhorn, P. (1998). Keuntin jeenyai (A return to mainland China). Bangkok: Thaipanit Bank.

Sirindhorn, P. (2009). Opening speech on the occasion of the 60th anniversary establishment of the People's Republic of China, open country reforms and development. Bangkok: Chulalongkorn University.

Raymond, G. V. (2019). Competing logics: Between Thai sovereignty and the China model in 2018. Southeast Asian Affairs, 2019(1), 341-358.

Rolland, N. (2020). China's vision for a new world order. Seattle: The National Bureau of Asian Research.

Ross, R. S. (2006). Balance of power politics and the rise of China: Accommodation and balancing in East Asia. Security Studies, 15(3), 355-395. doi:10.1080/ 09636410601028206

Rumelili, B. (2004). Constructing identity and relating to difference: Understanding the EU's mode of differentiation. Review of International Studies, 30(1), 27-47. doi: $10.1017 /$ S0260210504005819

Shambaugh, D. (2015). China's soft-power push: The search for respect. Foreign Affairs, 94(4), 99-107.

Shekhar, V. (2012). ASEAN's response to the rise of China: Deploying a hedging strategy. China Report, 48(3), 253-268. doi:10.1177/0009445512462314

Shin, G. (2006). Ethnic nationalism in Korea: Genealogy, politics, and legacy. Stanford: Stanford University Press.

The Standard. (2019). Poet prawat phonek prayut chanthaocha [Open the history of General Prayut Chan-o-cha]. Retrieved from https://thestandard.co/prayut-chan-o-cha/

Thairath. (2013, April 2). Somdetprataypratnaratsooda sayambawnmaratgoomareemit teedeeteesoot nailok kawngbhrachatna chaojeen (Princess Sirindhorn, the truly greatest friend of the Chinese people). Thairath. Retrieved from https://www. thairath.co.th/content/336193 
Snyder, S. (2009). China's rise and the two Koreas: Politics, economics, security. Boulder, CO: Lynne Rienner Publishers.

Sonoda, S., \& Goodman, D. (Eds.). (2018). China impact: Threat perception in the AsiaPacific region. Tokyo: Tokyo University Press.

Statista. (2020). Most important countries of origin of foreign tourists in China in 2018 Retrieved from https://www.statista.com/statistics/234149/tourists-in-chinaby-country-of-origin/

Storey, I. (2015). Thailand's post-coup relations with China and America: More Beijing, less Washington. Singapore: ISEAS Publishing.

Suzuki, S. (2015). The rise of the Chinese 'Other' in Japan's construction of identity: Is China a focal point of Japanese nationalism? The Pacific Review, 28(1), 95-116. doi: 10.1080/09512748.2014.970049

Tejapira, K. (2020). A tick on the dragon's back: How Siam bonded itself to China's political and economic supply chains. Situations: Cultural Studies in the Asian Context, 13(1), 5-30.

Thirawit, K. (2005). Jeenmai nai sotwattee 21 [New China in the 21st century]. Bangkok: Matichon.

Tungkeunkunt, K., \& Phuphakdi, K. (2018). Blood is thicker than water: A history of the diplomatic discourse' China and Thailand are brothers. Asian Perspective, 42(4), 597-621. doi:10.1353/apr.2018.0027

VOA News. (2019). Thai universities tap into rising Chinese demand. Retrieved from https://www.voanews.com/east-asia/thai-universities-tap-rising-chinese-demand

Webb, J., Schirato, T., \& Danaher, G. (2002). Understanding bourdieu. Crow Nest: Allen\&Unwin.

Whitney, C., \& Shambaugh, D. (2008). Soft Power in Asia. Chicago: The Chicago Council on Global Affairs. Retrieved from https://www.brookings.edu/wp-content/ uploads/2012/04/0617_east_asia_report.pdf.

Wike, R., Silver, L., \& Castillo, A. (2019, April 29). Many across the globe are dissatisfied with how democracy is working. Pew Research Center. Retrieved from https://www.pewresearch.org/global/2019/04/29/many-across-the-globe-are-dissatisfied-with-how-democracy-is-working/

Wongsurawat, W. (2019). The Crown and the Capitalists: The Ethnic Chinese and the Founding of the Thai Nation. Seattle: University of Washington Press.

Woo, J. (2020, September 7). 'Anboneun migug, gyeongjeneun junggug' majneun malinga? [Is it right to say 'the US for security and China for economy'?]. Maeil Business News. Retrieved from https://www.mk.co.kr/opinion/contributors/view/ 2020/09/920166/

Xinhua. (2018, August 25). Thailand can learn from China's development model: Thai deputy PM. Xinhua. Retrieved from http://www.xinhuanet.com/english/2018-08/ 25/c_137416690.htm

Ye, M. (2016). Understanding the economics-politics Nexus in South Korea-China relations. Journal of Asian and African Studies, 51(1), 97-118. doi:10.1177/ 0021909615585179

Yun, B. (2014). Dinner remarks by H.E. Yun Byung-se Minister of Foreign Affairs at the 9th Jeju Forum for peace and prosperity. Retrieved from http://www.mofa.go. $\mathrm{kr} / \mathrm{eng} / \mathrm{index}$.do

Zawacki, B. (2017). Thailand: Shifting ground between the US and a rising China. London: Zed Books.

Zhang, J. (2014). Seeking the Beijing consensus in Asia: An empirical test of soft power. Saarbrücken: LAP LAMBERT Academic Publishing. 